\title{
NABOKOV VS. DOSTOEVSKY: THE DUALITY OF STANDARDS AND A UNIVERSAL MESSAGE CONVEYED
}

\author{
Mohammed Amine BELAID ${ }^{1}$ \\ Imane Hind SARI ${ }^{2}$
}

${ }^{1}$ AbouBekr Belkaid University of Tlemcen, mohammedamine.belaid@ univ-tlemcen.dz, ORCID: 0000-0003-1318-1034

${ }^{2}$ AbouBekr Belkaid University of Tlemcen, imene.hind.sari@outlook.com, ORCID: 0000-0001-6298-3063

Belaid, Mohammed Amine; Sari, Imane Hind. "Nabokov vs. Dostoevsky: The Duality Of Standards and a Universal Message Conveyed". ulakbilge, 61 (2021 Haziran): s. 821-831. doi: 10.7816/ulakbilge-09-61-01

\begin{abstract}
Literature underwent thousands of phases that caused people to react distinctly to the endless fluid of literary perception. The purpose of this study is to highlight the impact this continuity of changes had and still have on literary criticism. To epitomize the previous idea, we had to juxtapose the lives of two writers who witnessed different eras: Dostoevsky and Nabokov. The two figures experienced their intertwined fates with variant attitudes and welcomed all the occurrences with an open mind, a number of life-changing works sprang up from their collections of events and particularly personal accounts. This paper also aims to psychologically apply the former nuances of Nabokov's criticism on Dostoevsky on his own writings in order to demonstrate the identical traits of the literary artist. The Jungian Theory served in this sense to bridge the gap between them and emphasize the emergence of the collective unconscious in the literary realm.
\end{abstract}

Keywords: community, criticism, Jungian Theory, collective unconsciousness 


\section{Introduction}

Nabokov's successful career as a critic is marked by his endless process of inquiring diverse positions of writers from different times and backgrounds. Among those writers, the specific position he maintained regarding Dostoevsky. Taking into consideration both his writing style and the themes around which his works revolve, with reliance on the explications provided by Jung, especially regarding the collective unconsciousness, offer a new way to approach the duality of standards found in every human being, that is, in every authentic writer.

This interconnectivity puts forth brand-new insights into the importance of universality and global understanding. The aim is not to show the differences that categorizes each of the writers but rather to juxtapose them as well as their visions. Nabokov had a lot to say about Dostoevsky, but in doing so he unlocked new dimensions for further studies. The conducted study is a glimpse of the applicability of psychology on literature and the fruitfulness of such processes with an intended universal message.

$\mathrm{X}$ and $\mathrm{Y}$ lived under the same roof, were born in the same year, witnessed the same sunsets but responded differently to whatever life threw their ways. This does not in any way put them in a position of contrast, instead juxtaposes the two of them and their responsiveness to the world around them. Juxtaposing concepts aroused from different fields of research and knowledge.

Juxtaposition as a literary device creates a euphemism to construct new ideas and perspectives. There is indeed a fine line between contrast, comparison and juxtaposition; while all of them put the studied elements on separate positions, juxtaposition classifies them within the same category and launches a new process in which the differences are not the primary inquiry. Beyond the conceptual way of benefiting from juxtaposition, it can as well be applied on human beings, their personalities, their capacities in addition to their discoveries, inventions and intentions.

It is, thus, hard to cast one's mind back to the originators of Juxtaposition. But what's worth noting is the instinctive tendency to juxtapose every single thing in life. Thus, this innate characteristic emphasizes not only the importance of such a process, but also its necessity to reach advancement and build up brand-new theories that work as stepping stones to successful discoveries.

\section{The Jungian Theory}

Carl Gustav Jung, the Swiss psychiatrist and the founder of analytical psychology, proposed a new approach to define the Psyche. Driven by both curiosity and determination he offered humanity access to a multi-dimensional universe of conflicting ideas, that reflects the chaotic nature of Man. The Psyche can be defined as the absolute formation of combined thoughts, behaviors, feelings and emotions, encompassing the spirit, the soul and the mind. It is composed of both consciousness and unconsciousness. To begin with, consciousness is designated as the Ego: the center of awareness. However, unconsciousness can be personal or/and collective. The literary function of collective unconsciousness is the crux of this research, as it reinforces the applicability of the Juxtaposition Theory on literature as a universal, cultural, educational and humanistic activity. As Jung put it:

The collective unconscious is anything but an incapsulated personal system; it is sheer objectivity, as wide as the world and open to all the world. There I am the object of every subject, in complete reversal of my ordinary consciousness, where I am always the subject that has an object. There I am utterly one with the world, so much a part of it that I forget all too easily who I really am. "Lost in oneself" is a good way of describing this state. But this self is the world, if only a consciousness could see it (Jung, 2002: 22).

All human beings share the same undefined role of being the way they are. This web of suppressed traits along with the continuity of the infinite inherited characteristics, which are expandable and expand as far as the human being exists, forge the Collective Unconsciousness.

The Collective Unconsciousness is: "a part of the psyche which can be negatively distinguished from a personal unconscious by the fact that it does not, like the latter, owe its existence to personal experience and consequently is not a personal acquisition" (Jung, 1999: 42). Therefore, the personal unconsciousness is accessible and genuinely prone to change since determination; which is the first step towards change, is approachable.

The number of experiences that frame the distinctive character of a person plays a considerable role in the latter process. None of the previous assumptions is compatible with the collective unconsciousness, which is, as a matter of fact, part of nature and none has, not even the minimal sovereignty, over it. Jung referred to the 
inevitability and the normality of this set of executed human tasks as "Archetype". To quote one more time Jung's sayings upon the matter:"From the unconscious there emanate determining influences which, independently of tradition, guarantee in every single individual a similarity and even a sameness of experience, and also of the way it is represented imaginatively" (Jung, 1999: 58).He explains: "They are not personalities, but are typical situations, places, ways and means, that symbolize the kind of transformation in question" (Jung, 38, 1999). And to blend this with the multiplicity of archetypes, he clarifies that: "There are as many archetypes as there are typical situations in life" (Jung, 1999: 48).

To fathom the previously mentioned points, juxtaposing two theories would bring about clarity into the subject. For example, Jung was not the only one to attribute such assumptions to the essence of existence; Karl Marx, for instance, advocated the idea of the flexibility of the human nature and the non-existence of the Core. Hence, socially speaking, society determines the nature of people. The Marxist view however was, if compared to the Jungian Theory, an external approach to the human nature, whereas the Jungian view focuses on the development of the Psyche, which takes place in the innards of the human being with the contribution of the inevitable external factors.

The applicability of such theories in the field of literature bears fruitful hypotheses and endless enjoyment trying to solve the lacking enigma of time and probabilities. Literature, hence, offers new w ays to demonstrate the necessity of creating suitable methods to apply theories in practice. Undoubtedly, the use of logic and critical thinking followed by analysis is a process of growth for both the one undertaking the research and for the audience.

\section{Vladimir Vladimirovic Nabokov}

The bilingual writer Vladimir Nabokov held a persistent refusal to acknowledge any cultural, historical and even literary influence on his art. He was born on the verge of a new century in 1899 and he indeed brought about new ways to approach literary works and even more to literary criticism that marked this new century. Bethea and Siggy explain:

For Nabokov, science and art are deeply related, and he challenges his readers to care about discovery the way a scientist should, and to bring that passion to their encounters with both artwork and the world. In its convergence with his art, Nabokov's entomological research demonstrates a way to think of science as part of a larger whole embracing all facets of human knowledge. Nabokov helps us see science within a larger context, one that includes art (Siggy, 2020: 193).

Science is not solely a body of knowledge; it is a universal process that builds itself with and in time.

For Vladimir, this human endeavour and art are correlated to a deep extent. As a lepidopterist, he mingled all the activities that sparkled his interest and created an instructive amalgamation of his own, that enables people to approximate science distinctly. He put it: "I discovered in nature the nonutilitarian delights that I sought in art. Both were a form of magic; both were a game of intricate enchantment and deception" (Nabokov, 1981: 63).

Nabokov's childhood was pleasant as the parental shield protected him from the horrific reality of war-time during the Russo-Japanese War. He encountered artistic spheres and was exposed to extraordinary Opera performances, played lawn tennis and attended several horses drawn sleigh rides. The persistence of learning reached the realms of visual art.

Moreover, regardless of his Russian origins, Nabokov acquired an early education on how to read and speak English before he could jot down a Russian word; this served him throughout his entire life and incisively during his twenty years in exile. He had been to many places including forty-six states in his adopted country of The United States of America. His liberal father Vladimir Nabokov moved his family to the Crimea when Lenin took over Russia, they had to split as his father remained in St. Petersburg who was tragically murdered when delivering a speech in 1922 .

His visual imagination permitted him to bring into existence an atmosphere of cosmopolitanism and considerable opulence. However, his self-determining individuality incited the authorial persona of Vladimir Nabokov as a multi-gifted individual.

\section{A Faithful Biography}

People have always felt the urge to pour out their emotions. Everything commences the moment something pops in their heads, it might be a recollection from the past; a smile, a thought, a slight detail that they might have 
missed, a word or perhaps the metabolism of repressed feelings which never made their appearance in the external, materialistic world, all which is marked by a shortness of breath.

Prior the process of recollection and memorization, the individual is challenged by the immensity of the message to be delivered, which keeps them frozen in time. They sit there, face to face with a blank page, boiling with rage, love and passion. Consumed by the idea of opening up to the world. In fact, sometimes they feel empty whenever the level of the difficulty to transliterate an internal battle into concrete composed morphemes increases. This stimulation resembles pondering upon the fanatic way in which life manifests itself at times.

The portrayal of reality, is not as easy as it sounds. While the authors' imagination is always on display, infusing life into fictional characters and attributing specific personality traits to each, is more of an entertainment. However, the task of uncovering one's entrails is preceded by the inner contention with the past, the pain and the foolishness life has evoked in them. Unless the author is able to cast his/her mind to an event peacefully, the words fail in the transmission of the text, writing it down would not only be $\mathrm{h}$ ard but would also lack coherence. Hence, the words jotted are more than just words, they once occurred, they tell a story of a survivor that managed to bury the hatchet of the past and move on. In 'Autobiography as philosophy' the importance that an autobiographical confession was recognized as an 'aid' for interpreters:

Even autobiographical passages that are more concerned with the broad social and cultural milieu of the writer can aid interpreters of the author's work. These will reveal patterns of friendship and hostility among writers, show which historical events are salient to the thinker and reveal facts that make allusive passages in the writer's other works clear (Dolinin, 1999: 5).

What history might deliberately turn a blind eye on, authors have explicitly exposed. And if history is prone to modification, personal accounts preserve the memories as they are, as well as their lasting impacts and impressions on the vulnerable writer.

\section{Nabokov's Eidetic Memory (Speak, Memory)}

"The present work is a systematically correlated assemblage of personal recollections ranging geographically from St. Petersburg to St. Nazaire, and covering thirty-seven years, from August 1903 to May 1940, with only a few sallies into later space-time" (Nabokov, 1989: 8). As deduced in the forward of the novel, Vladimir Nabokov's ability to render more than thirty-seven years into a collection of short stories effectively revolts against the traditional method of self-written biographies. Each chapter is dedicated for one specific period of his life. The sections stand together as one beautifully written masterpiece. The details are crafted in a manner that puts in display his life in the imaginary scene of the readers, so much like literature in motion, the writer of Lolita confessed: "The fact of vividly recalling a patch of the past is something that I seem to have been performing with the utmost zest of all my life..." (Nabokov, 1989: 39).

His mother's contributions to maintain and help improve the divine gifts he began too early to exert, are repeatedly mentioned in the first chapter: "My mother did everything to encourage the general sensitiveness I had to visual sensations" (Nabokov, 1989: 21).As a child, he experienced 'sensory hallucinations' and 'coloured hearing'. Nabokov's memory allowed him to not only savour the past, but to learn from it. Past held a dear place in Nabokov's heart and this is best perceived in his own words: "One is always at home in one's past" (Nabokov, 58, 1989). It takes a brave heart to find delight in what has long passed, specifically when the beginning of the end approaches. Nabokov's attitude regarding the past proves how well he made the most out of everything he stumbled on: "I witness with pleasure the supreme achievement of memory, which is the masterly use of innate harmonies when gathering to its folds the suspended and wandering tonalities of the past" (Nabokov, 1989: 89).

His revolting inclinations towards the unusual and the authentic are strongly evoked. However, the more one reads his autobiography, the more one gets lured into the optimistic image he maintained regarding time. He enfolded his hopes in the future: "I recall one particular sunset...my marvellous tomorrow ready to be delivered to me" (Nabokov, 1989: 109).And observing his child growing, he was convinced that the human nature always rises to the surface: "...there is in every child the essentially human urge to reshape the earth..." (Nabokov, 1989: 152).

\section{Dostoevsky's Divergent Reminiscence (The House Of The Dead)}

It is easy to extract the essential from his memoir, his humanistic intentions were plain even to the blind, Siggy in his essays that hinge on Russian Literature, put it as follows: 
House of the Dead appears to be, on the surface, an extremely simple book. It contains the memoirs of Dostoevsky's years in the prison camp, and for the readers of his time it brought to public scrutiny a whole world hitherto concealed from their gaze. Here was a gallery of peasant-criminals, most of whom had committed at least one murder, and about whom nobody else had ever written with such intimate knowledge. The aim of the work was to reveal their lives and their psychology, depicted, so far as possible, from their own point of view. Dostoevsky was in a unique position to accomplish this task because his sentence had placed him, unlike other members of his class, on the same social level as the peasant-convicts..." (Siggy, 2018: 20).

Anyone who reads his personal memoir is conscious of his urge to expose the injustice and cruelty that contaminated the prison. He put into question the necessity of punishment, is it really necessary to make a human being curse his own existence? Is not existence supposed to be a gift? And what made people believe that torture and brutality can lead to correction? All these questions and more were depicted in plain honesty.

Instead of erupting with rage, at the time he was writing this book, Dostoevsky made a new discovery about himself which consisted of the overflowing degree of self-control which consequently conveyed dozens of messages remarkably controlled and restrained. Along with being one in a million work to communicate prison life in such a way, Dostoevsky proved the contingency of using a fictional character as a mouthpiece. The professionalism and precision he relied on, later on, served scholars and philosophers to assume that:"The first thing to note is that the use of the first person is neither a necessary nor a sufficient condition for a work's being classified as autobiographical" (Thompson, 1999: 15).

His duty as a writer was to contribute in the maintenance of history. He humbly fulfilled his mission. Even though it took an awful long time for the flower to bloom, the fruitfulness of his words resonated for ages and still does. No aspects of prison life and its morbid routine are neglected in this account. Clear as crystal, he experienced it personally and with such an intensity that is beyond compare. The alienation he experienced during his prison life caused him to question the ways he should behave and the attitudes he should take up before the convicts. Integration was never achieved; he was always pushed aside for being different: "I was an outsider, and how peculiar my position was in prison." (Dostoevsky, 1962: 263).

The central theme for Dostoevsky was the individual. It is not enough to preach about life and its vicious ways that impose transformation on individuals. The endurance and responsiveness of the individual is what makes of literature capable of changing the world. As Thompson emphasized: "For Dostoevsky, the individual was the most important element of Russian culture...Dostoevsky said that 'universal responsiveness' is an essential trait of the Russian national character" (Thompson, 1999: 126). The universality that categorizes his works makes people connect across distance and time.

\section{Nabokov And Dostoevsky: Fates Intertwined}

\section{Hypersensitivity}

Nabokov more than once found fault with Dostoevsky's high sensitivity. In 'Speak Memory,' for example, he exploited the literary disposition of Dostoevsky to express his own position: "Heart-to-heart talks, confessions in the Dostoevskian manner, are also not in my line" (Nabokov, 1989: 143). In fact, this may also be regarded as a rejection of human nature. It is absolutely normal for human beings to find solace in words. Even the glass when it is overfilled the water is poured. Such is the heart; relief is only found in exchange of words.

Perhaps, the blame is on science. But life is not as plain as a scientific approach, it has its own unp redicted games, often pursued by a series of unforeseen breakdowns. Nabokov himself admitted the impossibility of such a combination: "...I found it no longer physically possible to combine scientific research with lectures, belle-lettres, and Lolita (for she was on her way- a painful birth, a difficult baby)" (Nabokov, 1989: 34).His dedication to literature interfered with his life, simply for the reason that writing is not just a matter of expression, it demands spiritual and physical dedication. Thus, literary works are parts of their writers: detaching this from that, is detaching part of their identity.

In a passage from 'Speak, Memory' Nabokov exposed himself to his readers:

Whenever I start thinking of my love for a person, I am in the habit of immediately drawing radii from my love-from my heart, from the tender nucleus of a personal matter - to monstrously remote points of the universe. Something impels me to measure the consciousness of my love against such unimaginable and incalculable things as the behavior of nebulae (whose very remoteness seems a form of insanity), the dreadful pitfalls of eternity, the unknowledgeable beyond the unknown, the helplessness, the cold, the sickening involutions and interpenetrations 
of space and time. It is a pernicious habit, but I can do nothing about it. (Nabokov, 1989: 149)

There are indefinite ways to express the immensity of love: the immensity that sometimes causes people to wonder their extremities. Some may turn to science, others to philosophy and many other forms of art and find nothing that might help them grasp the complexity of this feeling.

Nabokov found this solace in an amalgamation of science and the unknown, defying the universe, he was spiritually compelled to juxtapose the vast universe on his love for people. He recognized the operation as instinctive. Put differently, repressing the instinct is the imprisonment of one's self. Thus, love led him where he was supposed to be, and often this self-realization leads up to literary probity.

However, if one takes into consideration the previous assumptions he made regarding Dostoevsky, confusion will float like a jellyfish in a sea of probabilities. Indeed, the 'heart-to-heart talks' he seems to disregard are irrepressible as part of the human nature.

Moreover, the vulnerability of the human nature is mostly felt in retrospection. One of the last lines he recorded in his memoir declaiming his wife reveals the inevitability of vulnerable reminiscence: "The years are passing, my dear, and presently nobody will know what you and I know" (Nabokov, 1989: 150). These words alone are enough to make people ponder upon the shortness of life, the value of things surrounding them, and the magic that arouses from pure reciprocated intentions and feelings. Although people try their hardest to get the most out of life and its continuous opportunities, only when they realize that their journey on earth is slowly fading in time, the bigger picture will reveal itself to them and all the ambiguity of life, slowly turns into an appreciation of what once was the source of their little joyful escapes.

Certainly, the impression one gets reading such powerful and explicitly decent confessions, is similar to getting lured into a bubble of a mixture of sadness and joy; that is to say, this experience resembles on many levels the Dostoevskian one. From this perspective, the Dostoevskian experience is at best lived when people are willing to wear their hearts on their sleeves and just swallow the truthfulness of the fact that nature is unstoppable and the best way to cope with is through acceptance. Dostoevsky has established a literary outreach that will live on. To put it briefly, he taught the world that the first step to self-discovery is to embrace one's nature. To exemplify, Baron Alexander Wrangel drew his own picture of Dostoevsky declaring:

I was always amazed by the superb humanity that glowed in Dostoevsky's soul, despite his grievous destiny, despite the prison, the exile, the terrible malady, and the eternal want of money. Not less was I astonished by his rare guilelessness and gentleness, which never left him even in his worst hour." (Wrangel, 1912: 308)

This brings clarity on whether his writings were 'heart-to-heart' serving the literary cause or simply as a revelation of what Dostoevsky was as a human being. One line of accuracy is enough to let people know that they are never as alone as they feel at times. One genuine depiction is sufficient to rescue the injured, and humanity owes this to Dostoevsky who fearlessly brought light into the obscure.

\section{The Inwardness of Imagery}

What lies beneath the crafted features of a face challenges the depth of oceans. Words, in fact, serve this matter as a means to prove that what is naked to the eye is just the surface, what account the most are the characteristics, which distinguish each person on the face of the globe. This diversity in literature is treated from different angles. While some rely on psychology others are entertained by the word-painting capacity of a writer.

The dynasty of Dostoevsky is still going strong today through the universal characters he created. Readers from all over the world, relate to the pervasive roles of both his major and minor characters. Siggy offered a glimpse of one of Dostoevsky's letters to his brother during his worst times:

I need money," he tells Mikhail bluntly. "I have to live, brother. These years will not have passed without bearing their fruits... What you spend for me-will not be lost. If I manage to live, I will return it with interest...and now I will no longer write trifles. You will hear of me being talked about." (Dostoevsky, 1962: 39)

Even at his lowest, he focused on his personal growth. He dismissed the idea of being just another martyr of time. On the contrary, he took off the negative and substituted it with a will to change, a message was awaiting the messenger, and he faithfully conducted it.

His promise to his brother was enhanced into a tremendous success: a success that he owes to reality. To epitomize the latter, in a passage from 'The House of the Dead' he brought into the open one of the truths he could never relate to, nor understand but as a universal messenger, he conveyed the messages as it is, with the same astonishment it caused him: "Only in prison have I heard stories of the most terrible, the most unnatural 
actions, of the most monstrous murders told with the most spontaneous, childishly merry laughter" (Dostoevsky, 2010: 16). The fact that he could not erase from his memory the impact it had on him ascertains the cruelty he forcedly had been exposed to.

However, he managed to survive the tragic occurrence of everything with repugnant goals. He scrutinized the intensity of each convict and above all, articulated their humanity even when he least expected it, and acknowledged that: "The impression made by the reality is always stronger than that made by description" (Dostoevsky, 2010: 32).

Nabokov, also, made known his devastating feelings with reference to his father's life. He could not rebuff the trauma that the idea of losing his father had kindled in his heart. In many instances, human beings experience an emotional breakdown that an imaginary scenario sparks off, Nabokov experienced similar grief as a child, on his way home believing his father's life was threatened, he spelled out recalling this specific day: "And behind it all there was yet a very special emotional abyss that I was trying to skirt, lest I burst into a tempest of tears, and that was the tender friendship underlying my respect for my father; the charm of our perfect accord..." (Nabokov, 1989: 98). However, his strong responsiveness operated equally for every situation he faced to the point that recalling such scenes produced in him as he deciphered: "A sense of security, of well-being, of summer-warmth pervades my memory. That robust reality makes a ghost of the present. The mirror brims with brightness... Everything is as it should be, nothing will ever change, nobody will ever die" (Nabokov, 1989: 39).The delicacy of word use is dynamically felt; he was aware of the fact that while some people live and die, they survive somewhere and no force in the universe has the power to undo what they achieved, yet he acknowledged the privilege of being what he was. The uniqueness of the role he played along with all the imperfect deeds he had performed, are what made him the writer of such a memoir. The delivered optimism is fuelled with a power of prevailing maturity.

Nabokov unveiled both the ups and downs with no alteration nor exaggeration, the same way Dostoevsky accurately observed the favourable outcome of an honest smile in The House of the Dead portraying a convict: "I love his smile, which always warm and tender" (Dostoevsky, 2010: 39). It is, therefore, indisputable that all great writers, in addition of their possession of piercing eyes, purity is a typical trait of theirs.

\section{Exile}

It is not about the destination but the way one departs. Both Nabokov and Dostoevsky underwent the woe of exile, however; they passed through their distinct phases variously and were affected on separate lines.

Nabokov left his homeland at a very young age, but his entourage revived the patriotic child in him as he acknowledged: "I was not quite six, but that year abroad, a year of difficult decisions and liberal hopes, had exposed a small Russian boy to grown-up conversations. He "could not help being affected in some way of his own by a mother's nostalgia and a father's patriotism" (Nabokov, 1989: 48). Only in retrospection Nabokov explained what once was astonishing for him and was finally able to label his parents' positions, which are described as divergent although both of them orbit the same central point: Russia. This might serve as a proof to the indefinability and the individuality of stances apropos the exile.

Each incident was essential for Nabokov to grasp the channelling events, functioning as a small portion that ended up forging his personality. Furthermore, the spiritual growth is a saintly journey of discovery that starts from the external changes and provocations, which inspire different reactions from the person. As a result of such a process, the personality traits are determined. On his journey of self-discovery, he relied on the similarities between occurrences to uncover truths, as presented: "thenceforth for several years, until the writing of a novel relieved me of that fertile emotion, the loss of my country was equated for me with the loss of my love" (Nabokov, 1989: 118).The intensity of the pain experienced at different times of life enabled him to conclude that: loss in all its forms, is traumatic. Detachment brings forth attachment, the longer the distance, the plainer the picture. Solitude brings birth to the essence.

In exile, Nabokov had the chance to meet his own self; he knew deep down that he belonged somewhere. Distance, hence, brought his country closer to his heart and pen, he assumed: "The story of my college years in England is really the story of my trying to become a Russian writer" (Nabokov, 1989: 132). It brought out the best in him as he started to gain new skills through several occupations: "In the course of my twenty years of exile I devoted a prodigious amount of time of the composing of chess problems" (Nabokov, 1989: 44). The composition of chess problems filled the gaps in his writings, it increased the value of his productivity and literary creativity. 
On the other hand, Dostoevsky's freedom was ripped out from him and the banishment put him in an institution of confinement, where he spent his youth imprisoned in a restrictive environment. Living without books was one of the toughest regulations he had to cope with: "And therefore, living without books I had unconsciously become absorbed in myself, set myself problems, tried to solve them, worried over them sometimes. But there is no describing all that!" (Dostoevsky, 1962: 304). While Nabokov found refuge in chess problems, Dostoevsky designed an intimate frame of mind where he expressed his thoughts to himself.

In addition to purity, problem solving is another worth-noticing trait that writers endowed with extraordinary talents, extremely exhibit. Emerson highlighted the terrible change in Dostoevsky's fate on distinct levels: "For Dostoevsky (1821-1881), the break was traumatic, geographical, and coerced from the outside" (Siggy, 2018: 145).

To acquire a glimpse of what life in prison would cause a person to reckon, Dostoevsky's personal account covers all possible accepts, he emphasized: "One recalls details which one would not remember at another time, and which one would not feel as one does then. And one speculates on the future, how one will get out of prison. Where will one go? When will that be? Whether one will return to one's native place." (Dostoevsky, 1962: 215). Confined between the walls, can be regarded as a revolting instance of the depths to which one can sink and degenerate in them. The complete depravity of something as precious as freedom had the power to destroy all moral tendencies and fix the root of offensive baseness. He put it:

"I may mention here parenthetically that our dreams and our long divorce from the reality made us think of freedom as somehow freer than real freedom, that is, than it actually is. The convicts had an exaggerated idea of real freedom, and that is no natural, so characteristic of every convict." (Dostoevsky, 1962: 305)

A portion of rationality is lost between those walls; the break was so ruthless that it disrupted their mere reasoning. The concept of freedom was altered in their eyes and put out of their reach, the only way to approach it was through imagination, and imagination (as boundless as it is) overestimates most things.

The most important lessons people are likely to receive are not from education but mostly from life. The lessons they learn the hard way occupy a unique place in their hearts; life is the teacher no one could miss its course as it never stops, no one is ready for the plots that are launched from the day they are born and forward. The set of qualities that made Dostoevsky and Vladimir distinct from one another and from the world is a combination of what life had taught each one of them. In Dostoevsky's words: "There is no standard by which to measure the soul and its development. Even education itself is no test" (Dostoevsky, 1962: 261).His primary goal as a writer was to depict the horrors of prison life, and experience for him was the approval which gave him permission to write about it as: "Some things one cannot judge without experience" (Dostoevsky, 1962: 268).

\section{Female Presence and Anima}

Parents play a tremendous role in the development of their children this is why the slightest gesture is carefully preserved in the memory of a child. At times parents live for their kids; they do not just look after their little ones, but observe each and every step they take. Often, the childhood activities offer some hints for the parents to determine their children's hobbies and leisure pursuits.

Nabokov's mother was cautious about his aural and optical hallucinations. He explained: "To my mother, though, this all seemed quite normal...My mother did everything to encourage the general sensitiveness I had to visual sensations" (Nabokov, 1989: 21). Her efforts as a supportive mother were transformed into a loving memory in his heart. Their circumstances strengthened their mother-child bond: "My numerous childhood illnesses brought my mother and me still closer together" (Nabokov, 1989: 22).

The female presence in Nabokov's life can be considered as a blessed assurance that allowed him to grow stronger and smarter. The inclusion of the women's role is acknowledged as both concrete and abstract. As a mindful child, he detailed the daily occurrences and the remarkable reactions of his mother through which she taught him the vulnerability of human beings neither by tricks nor by force but simply by example. To give an instance of the latter: "My mother knew well how hurtful a broken illusion could be. The most trifling disappointment took on for her the dimensions of major disaster". (Nabokov, 1989: 26).He learnt a great deal following the footsteps of his mother and her profound humanity. In addition to that, she taught him how to love unconditionally: "To love with all one's soul and leave the rest to fate, was the simple rule she heeded". (Nabokov, 1989: 23). To welcome love with no fear and to give without counting is one out of the thousand ways he recalled his mother, who was once his biological mentor. 
Nabokov is not the only one who drew attention to the immeasurable, exceptional and noble warmth of a woman's love. Dostoevsky's last and happiest years of his life were spent in the company of his wife the stenographer Anna Grigorievna Dostoevskaya. Her mere presence has changed his vision of life as she offered him variant motives to hold onto life. She paved the way for her husband to write his most successful novels and above all made of him a caring father.

In a letter to Apollon Nikolayevitch Maikov, Dostoevsky let his heart pour itself to his friend:

I was afraid that Anna Grigorovna would find life with me a tedious thing. For up to the present we have been literally alone. Of myself I could hope little: my nature is morbid, and I anticipated that she would have much to bear from me. (N.B. Anna Grigorovna indeed proved herself to be of a nature much stronger and deeper th an I had expected; in many ways she has been my guardian angel; at the same time, there is much that is childish and immature in her, and very beautiful and most necessary and natural it is, only I can hardly respond to it. All this I saw vaguely before ours. departure; and although, as I said, Anna Grigorovna is finer and stronger than I had guessed, I am not even now free from all uneasiness.)" (Dostoevsky, 1962: 144)

They certainly were a match made in heaven, she was exactly what he failed to be and they gave each other what they needed which made them forget about what they wanted.

As a gambler, Dostoevsky's experience with gambling cost him a lot as it became compulsive and consumed all his being. The Gambler is one of the most autobiographical of all his works regardless of the fact that it is thinly disguised as fictional, it actually narrates the account of his struggle with gambling. The enslavement of a roulette that is in fact not fun, but dark and more like a self-destructive process. Shedding light on his work is important if one considers the circumstances under which the story was written. As a remarkable achievement, it was written in twenty-five days as he needed money. With the help of the stenographer who later would become his wife, they successfully finished it within such restrictions. They married short after its publication; all this to highlight that even though theymet when he was at his lowest, she helped him to get back on his feet and shine brighter than any other time, he told his friend:

I lost not only what I had won, but also my own money down to the last farthing; I got feverishly excited, and lost all the time. Then I began to pawn my garments. Anna Grigorovna pawned her last, her very last, possession. (That angel! How she consoled me, how she suffered in that cursed Baden, in our two tiny rooms above the blacksmith's forge, the only place we could afford I) At last I had had enough; everything was gone. (Dostoevsky, 1962: 119)

In another letter to his sister Vera, and his Brother-in-Law Alexander Pavlovitch Ivanov, he recognized his duty as a father and disclosed his willingness to concretize his intentions to become better: "At the end of February, Anna Grigorovna will be a mother, and for that occasion I must absolutely have money" (Dostoevsky, 1962: 139).

From a Jungian perspective, any man on earth holds an unconscious feminine side which manifests itself unconsciously. Jung coined the term 'Anima' to denote the invisible barrier that separates the individual consciousness consisting of the ego from the collective unconsciousness. First, according to Jung the collectiveness hailed from the inheritance of the elements that all humans have in common. Furthermore, in spite of the fact that all people share similarities, the uniqueness of each individual is alerted through the process of Individuation. Individuation is designated as a self-realization operation that inspires a robust functioning of individuality and personality. This leads to the multiplicity of the ways through which archetypes manifest differently in each person. Hence, personalities are units of sub-elements. Anima is one of those elements, it is as previously explained the feminine side of a man. It is experienced differently but outlines a crucial role that when detached or lost causes a disequilibrium: "After the middle of life, however, permanent loss of the anima means a diminution of vitality, of flexibility, and of human kindness" (Jung, 1999: 71).If a man is willing to accept and work on his anima his heart will be trained to love and care beyond limits.

Nabokov by pointing out Dostoevsky's high sensitivity, he neglected and, in some ways, rejected his Anima. However, the previous analysis of his memoir 'Speak Memory' is an evidence of his own sensitivity that, combined with his incredible talent successfully transported an impressive tenderness by means of words. Without a scintilla of doubt, out of all the reasons Jung categorized both the Anima and the Animus as separate contra-sexual archetypes one is because women and men respond differently to the daily occurrences. Additionally, even if it may sound stereotypical that women feel more intensely and that emotional regulation is mostly controlled by gender differences, they are different in fact but they also complete each other. Denying the 
archetypical metabolism does not take it apart from its origins. Despite Nabokov's criticism regarding sensitivity, he himself transcribed his emotions frequently and deliberately.

\section{Nabokov on Dostoevsky}

Critics were once simple readers that slowly developed their critical skills, and later on shared their opinions with the world. Without a shadow of doubt, criticism is not done randomly. A critic has to read between the lines, keep track of books, and adopt an objective sense of judgement, which does not completely deprive them from expressing their opinions deliberately but the critic is required to critically conform to the literary rules under which criticism is dealt with properly. Nabokov left his mark on the literary world with his literary reviews that altered the literary realm on many levels. What is remarkable about Nabokov's legacy are his changing views that reflect his endless quest. One of the best examples which bears this literacy improvement and unsteadiness is his criticism on Dostoevsky. The first thing to hint at is the criticism he received regarding his prior criticism on Dostoevsky. As pointed out by Dolinin:

Nabokov's flippant critique of Dostoevsky in his American years can be explained as a response to philosophical and religious interpretations of the writer prevalent in the American academy of the1950s and 1960s. In a different Russian context of the 1930s, he took a much more favourable view of the 'author of The Double and The Possessed' (Gift 339), praised the masterfully constructed narrative of The Brothers Karamazov and called Dostoevsky a 'writer of keen perception' - one of the highest compliments on his scale of aesthetic appraisal." (Dolinin, 1999: 122)

Therefore, as signalled above, his criticism was inevitably affected by his experiences in exile and thus was geographically and culturally based. Dostoevsky displayed a style and background that were rooted in the Russian tradition. Logically speaking, Nabokov's academic journey abroad developed in him a sharp sense of valuing and weighing words distinctly from a number of angles. In his critical work entitled Vladimir Lectures on Russian Literature he acknowledged the nature of his thoughts on Dostoevsky:

My position in regard to Dostoevsky is a curious and difficult one. In all my courses I approach literature from the only point of view that literature interests me - namely the point of view of enduring art and individual genius. From this point of view Dostoevsky is not a great writer, but a rather mediocre one-with flashes of excellent humor, but, alas, with wastelands of literary platitudes in between (Nabokov, 1981: 68). The words he used to classify Dostoevsky are at the same time clashing and complementary. Knowing that he held more than one way to approach literature, it was hard for him to quit pondering upon the overflowing shades of Dostoevsky. This led him to many ends and also nourished his curiosity which brought into being a groundless critical study. He went on mirroring Dostoevsky's incidents on his writings. Precisely The House of the Dead which he sharply described as unpleasant to read since it narrates the worst times of his life. He put it as follows:

The four years of penal servitude Dostoevsky spent in Siberia in the company of murderers and thieves, no segregation having been yet introduced between ordinary and political criminals. He described them in his Memoirs from the House of Death (1862). They do not make a pleasant reading. All the humiliations and hardships he endured are described in detail, as also the criminals among whom he lived. Not to go completely mad in those surroundings, Dostoevsky had to find some sort of escape. This he found in a neurotic Christianism which he developed during these years (Nabokov, 1981: 69). He jumped from prison life to his religious tendencies in one sentence, which pictures his quest for answers. However, the descriptions provided in Dostoevsky's novel are more than just simple descriptions they portray his own vision of life, justice, punishment and religion. Literature is boundless and there is room for everyone: Nabokov depicted his life in a memoir the same way Dostoevsky poured his heart to his readers. The only difference that determines their deviation from each other is their motives. Dostoevsky wanted to change the horrific reality and as a writer it was the least he could offer to the people who endure hardships every single day to satisfy others' ego and lust for power.

In addition to that, religion can indeed be a refuge and faith is itself an answer to many questions. Jung classified religion as archetypical and this can be interpreted differently: "Almost the entire life of the collective unconsciousness has been channelled into the dogmatic archetypical ideas and flows along like a well-controlled stream in the symbolism of creed and ritual" (Jung, 1999: 12). Taking into consideration the fact that archetypes express themselves differently in each individual could be one of the interpretations. But as an intellect, Dostoevsky's faith was not grounded overnight.

The next criticism Nabokov asserted about Dostoevsky is neither of positive manifestation nor negative; it 
totally demonstrates his objectivity and scrutiny. He inspected intensely the distinct influences that according to him reached Dostoevsky on many occasions and altered his writings: Dostoevsky never really got over the influence which the European mystery novel and the sentimental novel made upon him. The sentimental influence implied that kind of conflict he liked-placing virtuous people in pathetic situations and then extracting from these situations the last ounce of pathos. When after his return from Siberia his essential ideas began to ripen the idea of salvation to be found through transgression, the ethical supremacy of suffering and submission over struggle and resistance, the defence of free will not as a metaphysical but as a moral proposition (Nabokov, 1981: 71). His statements are way too direct and misinterpret the reality of the intentions that lay an anchor to the windward for Dostoevsky's humanitarian motives. The problem Nabokov continuously indicated is mostly related to the ways Dostoevsky wanted and did express himself in. People are directly exposed to invisible influenc es and this is part of the process. What is important is how they use such influences. For this case, universal influences created a universal writer, who lifted his pen and left his mark on the universe, Nabokov's changing views on Dostoevsky exhibit both the universality and prosperity of his works.

\section{Conclusion}

The underlined common grounds of both Nabokov and Dostoevsky are gathered in this paper to establish a new perspective that assures the reconciliation of the opposites. Nabokov frequently held a disturbed position when criticizing Dostoevsky, and this same disturbance propelled the researchers to juxtapose them relying mainly on two of their autobiographical works that were crafted differently yet with at least one shared motive: The House of the Dead and Speak, Memory.

Counting on Jung's findings, the researcher endeavoured to connect the dots and prove how human beings are different indeed, but the universal traits that assemble them are irrepressible and manifest themselves instinctively and spontaneously. The universal message that is conveyed bears in its folds the beauty of authenticity along with the peaceful atmosphere that an author has the power to establish by means of honest words.

The interconnectivity of spheres is another layer of the message as it encloses works and hypotheses from different eras and cultures. This diversity and its fertile origins lay a foundation of new studies and unlimited area of perceiving literature. Or in Jung's words: "A million zeros joined together do no unfortunately add up to one."

Even though both writers occupy different standpoints, certain points intertwine and meet in the middle. The existence of literary differences inspires creativity as well as innovation and thus leads to brand new outcomes, contrary to stagnation and repetition which not only are impossible to keep up, but also draw an infinite circle that takes nowhere but to the same explored places.

\section{References}

Bethea, David, and Siggy Frank. "Contextualising Nabokov." Vladimir Nabokov in Context, Apr. 2018, pp. 1-8., doi:10.1017/9781316258132.001.

Bethea, David, and Siggy Frank. Vladimir Nabokov in Context. Cambridge University Press, 2020.

Dolinin, Alexander. "Nabokov, Dostoevsky, and 'Dostoevskyness." Russian Studies in Literature, vol. 35, no. 4, 1999, pp. 42-60., doi:10.2753/rsl1061-1975350442.

Dostoyevsky, Fyodor. Letters of Fyodor Dostoyevsky: to His Family and Friends. Translated by Ethel Colburn Mayne, Peter Owen, 1962.

Dostoyevsky, Fyodor. The House of the Dead: a Novel in Two Parts. Translated by Constance Garnett, Wordsworth Editions, 2010.

Emerson, Caryl. The Cambridge Introduction to Russian Literature. Cambridge University Press, 2008.

Frank, Joseph. Between Religion and Rationality: Essays in Russian Literature and Culture. Princeton University Press, 2010.

Jung, C., and Herbert Read. The Collected Works of C.G. Jung, Vol. 9, Part 1: Archetypes and the Collective Unconscious. Routledge, 1990.

Jung, Carl, and Anthony Storr. The Essential Jung: Selected Writings. Princeton University Press, 1999.

Kelly, Catriona. Russian Literature: a Very Short Introduction. Oxford University Press, 2001.

Mathien, Thomas, and David Wright. Autobiography as Philosophy: the Philosophical Uses of Self-Presentation. Routledge, 2010.

Nabokov, Vladimir, and Fredson Bowers. Lectures on Russian Literature. Harcourt / Bruccoli Clark Layman, 1981.

Nabokov, Vladimir. Speak, Memory: an Autobiography Revisited. Vintage, 1989.

Thompson, Ewa. The Search for Self-Definition in Russian Literature. Rice University Press, 1991. 